Minireview

\title{
Time line of discoveries: anoxygenic bacterial photosynthesis
}

\author{
Howard Gest ${ }^{1}$ \& Robert E. Blankenship ${ }^{2, *}$ \\ ${ }^{1}$ Department of Biology, Indiana University, Bloomington, IN 47405, USA; ${ }^{2}$ Department of Chemistry and \\ Biochemistry, Arizona State University, Tempe, AZ 85287-1604, USA; *Author for correspondence (e-mail: \\ Blankenship@asu.edu; fax: +1-480-965-2747)
}

Received 17 April 2003; accepted in revised form 3 September 2003

Key words: anoxygenic photosynthetic bacteria, green bacteria, heliobacteria, history of photosynthesis, purple bacteria

\begin{abstract}
A time line of important research relating to anoxygenic photosynthetic organisms is presented. The time line includes discoveries of organisms, metabolic capabilities, molecular complexes and genetic systems. It also pinpoints important milestones in our understanding of the structure, function, organization, assembly and regulation of photosynthetic complexes.
\end{abstract}

Abbreviations: BChl - bacteriochlorophyll; Bph - bacteriopheopytin; EPR - electron paramagnetic resonance; GTA - gene transfer agent; $\mathrm{P}$ - photoactive pigment; $\mathrm{RC}$ - reaction center; TCA - tricarboxylic acid cycle

\section{Introduction}

Why list scientific discoveries in a time line? There are at least four answers. A time line is a condensed history showing how understanding of a particular problem or science blossoms from its 'roots.' Secondly, it reveals, more or less at a glance, how basic discoveries lead to new findings in ever-increasing detail. Thirdly, it should remind us that at many stages of a time line, scientists must have erroneously believed that 'breakthroughs' they experienced during their most productive years represented advanced understandings that would not be greatly altered by subsequent research. Fourthly, it instills deservedly greater respect for the efforts and insights of our predecessors. Although their names are frequently not mentioned, their fundamental discoveries are usually discussed at the beginning of seminars, before the speaker plunges into molecular and other details. Interested readers are also referred to a general timeline of photosynthesis by Huzisige and Ke (1993). A time line of discoveries in oxygenic photosynthesis is presented by Govindjee and David Krogmann (this issue).
In the time line, names of organisms are given as they appeared in original publications. Appendix A lists alternative names of some anoxyphototrophs that have been prominent in research over the past 50 years. Some important events in the general history of bioenergetics research are also included in the time line to serve as 'mileposts.' References are divided into two sections. Appendix B contains general references, which are primarily secondary sources and are included as an entry to the primary literature. The section labeled as 'References' refers to specific landmark papers that are cited in the text. Not all entries in the time line have cited references, but a combination of the cited and general references should permit the interested reader to find primary reports for any of the milestones listed in the time line.

As requested by the editors, a photograph of the authors is shown in Figure 1.

\section{Beginnings (1873-1876)}

Sir E. Ray Lankester (1847-1929) was a prominent biologist who did research on a wide variety of 


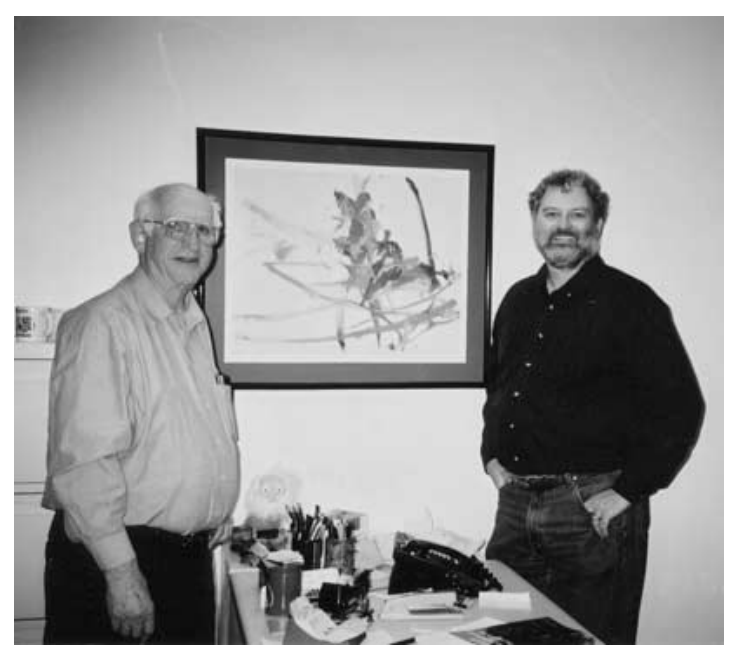

Figure 1. Photograph of the authors: Howard Gest (left), Robert Blankenship (right). Photo taken at the Arizona State University, Tempe, Arizona, in February 2002.

organisms, from protozoa to mammals. Lankester made the first observations of purple photosynthetic bacteria in enrichment cultures, associated with the decay of organic matter (e.g., dead worms) in water. In 1876 he noted red-colored 'crusts' resembling the colored films that form on the sides of a bottle of Burgundy wine. Lankester designated the pigmented bacteria as 'Bacterium rubescens' and made preliminary attempts to characterize the pigment, which he called 'bacteriopurpurin.'

\section{3}

Theodor W. Engelmann (1843-1909) reported that in a dispersed spectrum, cells of the purple 'Bacterium photometricum' accumulated at specific wavelengths, including a band in the infrared. Failure to detect production of $\mathrm{O}_{2}$ led him to doubt that the organism was truly photosynthetic, at least as the process was then defined (Engelmann 1883). Subsequent research by Engelmann in 1888 led him to conclude that 'bacteriopurpurin is a true chlorophyll.' S. Winogradsky later identified Engelmann's culture as a mixture of Chromatium species (Winogradsky 1888).

\section{4}

Dr Charles MacMunn, an Irish physician, discovers cytochromes in a variety of animal tissues, but eminent chemists believe he is merely observing breakdown products of hemoglobin (see 1925).
1887

Erwin von Esmarch (1855-1915), a medical bacteriologist, isolates a spiral-shaped bacterium from a dry mass, originating from a sample of Berlin tap-water in which a dead mouse had decayed. He grew the bacterium as a heterotroph and named it Spirillum rubrum. In 1907, Molisch concluded that it was a nonsulfur purple photosynthetic bacterium and renamed the bacterium Rhodospirillum rubrum (see 1907).

\section{8}

S. Winogradsky, discoverer of chemoautotrophy, describes purple sulfur bacteria (including Chromatium) that develop on the illuminated side of a 'Winogradsky column.' To prepare the column, a large glass cylinder is packed with mud mixed with organic matter, $\mathrm{CaCO}_{3}, \mathrm{CaSO}_{4}$, and overlain with lake, pond or ditch water. The column is incubated in a north window, where it receives adequate illumination (Winogradsky 1888).

\section{7}

Hans Molisch (1856-1937) pioneered in isolating and describing a number of species of nonsulfur purple bacteria in pure culture, including Rhodonostoc capsulatum, later renamed Rhodopseudomonas capsulatus (Molisch 1907). He demonstrated conclusively that $\mathrm{O}_{2}$ is not produced by such organisms, and also discovered the photoheterotrophic growth mode. Molisch separated two pigments from purple bacteria, retaining the name 'bacteriopurpurin' for the red pigment. He designated the green pigment 'bacteriochlorin.'

\section{2}

G.A. Nadson describes the green bacterium Chlorobium limicola, which was later isolated and studied in pure culture by van Niel (1932).

\section{5}

David Keilin, in Cambridge, UK, rediscovers cytochromes. Keilin spent his entire career working on cytochromes, examining their redox behavior and distribution in a wide variety of cell types. 
K. Lohmann, C.H. Fiske and Y. Subbarow isolate and characterize ATP.

\section{1}

Keita Shibata publishes 'Carbon and Nitrogen Assimilation' (1931). Shibata's theory of photosynthesis assumed the photodissociation of water and he also proposed a general interpretation of the metabolism of anoxygenic photosynthetic bacteria that was very similar to Cornelis B. van Niel's scheme. It is very likely that Shibata and van Niel developed their hypotheses independently.

\section{2}

From his studies on purple sulfur bacteria, van Niel (1897-1985) concludes that:

For the process of photosynthetic carbon dioxide assimilation (or reduction) we may then say that the reaction

$$
\mathrm{CO}_{2}+2 \mathrm{H}_{2} \mathrm{~A}=\mathrm{CH}_{2} \mathrm{O}+\mathrm{H}_{2} \mathrm{O}+2 \mathrm{~A}
$$

requires various and special compounds of hydrogen for various and special organisms. From which it follows that the photosynthetic activity of the chlorophyll-bearing organisms, in which $\mathrm{H}_{2} \mathrm{~A}$ represents $\mathrm{H}_{2} \mathrm{O}$, represents only one very special instance of a group of possible photosynthetic activities. This would mean that the purple sulphur bacteria can use $\mathrm{H}_{2} \mathrm{~S}$ as a hydrogen donor, but cannot use $\mathrm{H}_{2} \mathrm{O}$. (van Niel 1932).

Robert Emerson and William Arnold publish two landmark papers in photosynthesis, demonstrating that most chlorophylls do not directly carry out photosynthesis. They proposed the concept of the photosynthetic unit, which consists of all the pigments that cooperate to carry out photosynthesis and the enzymes that do the actual chemistry. While these experiments were carried out with the oxygen-evolving green alga Chlorella, the concept of the photosynthetic unit is essential for the later development of the concept of separable antenna and reaction center complexes in both oxygenic and anoxygenic photosynthetic organisms (Emerson and Arnold 1932a, b; also see Clayton 2002).
F.M. Muller demonstrates that purple sulfur bacteria can grow photosynthetically under anaerobic conditions in media containing simple organic carbon sources in the absence of oxidizable inorganic sulfur compounds. Growth was accompanied by production or utilization of $\mathrm{CO}_{2}$, depending on the 'redox level' of the organic substrate. With lactate, pyruvate, succinate or malate, there was a net production of $\mathrm{CO}_{2}$; with butyrate, growth required addition of $\mathrm{CO}_{2}$.

\section{6-1938}

Starting in 1936, Harland Wood and colleagues obtain evidence showing that heterotrophic propionic acid bacteria utilize $\mathrm{CO}_{2}$ for formation of $\mathrm{C}_{4}$ dicarboxylic acids (via $\mathrm{C}_{1}+\mathrm{C}_{3}$ condensation). This was the first evidence that incorporation of $\mathrm{CO}_{2}$ into organic compounds was not limited to photosynthetic or chemosynthetic autotrophs. Wood's research paved the way for later characterization of carbon metabolism in $\mathrm{C}_{4}$ plants (sugar cane, maize, etc.).

Hans A. Krebs describes the tricarboxylic acid cycle, otherwise known as the citric acid cycle or the Krebs cycle. This is the primary metabolic machinery that furnishes the reducing power for energy-yielding respiration of many kinds of cells.

Otto Warburg and W. Christian discover FAD (Flavin adenine dinucleotide) and explain the basic roles of NAD and NADP in metabolism.

\section{0}

Samuel Ruben and Martin Kamen discover ${ }^{14} \mathrm{C}$. In earlier (frustrating) attempts to trace the path of carbon in photosynthesis, they used short-lived ${ }^{11} \mathrm{C}$ (see $\mathrm{H}$. Gest, this issue). The use of ${ }^{14} \mathrm{C}$ as a tracer played a major role in elucidation of metabolic mechanisms (including the Calvin/Benson cycle) and also led to the ${ }^{14} \mathrm{C}$ radiocarbon method for dating archaeological and historical artefacts. See also Benson (2002).

\section{4}

C.B. van Niel publishes an extensive study on characteristics (general physiology and pigments) of nonsulfur purple species that later became major experimental organisms for exploring 
bacterial photosynthesis, including Rps. capsulatus, Rhodopseudomonas sphaeroides, and Rsp. rubrum (van Niel 1944).

\section{9}

H. Gest and M.D. Kamen discover light-dependent production of $\mathrm{H}_{2}$ and $\mathrm{N}_{2}$ fixation by Rsp. rubrum. Subsequent studies revealed that many anoxygenic phototrophs have $\mathrm{N}_{2}$ fixation capacity (Gest and Kamen 1949; Kamen and Gest 1949), and that Rsp. rubrum can use $\mathrm{H}_{2}$ and $\mathrm{CO}_{2}$ (as sole carbon source) for photoautotrophic growth in a synthetic medium (Ormerod et al. 1961). Both light-dependent $\mathrm{H}_{2}$ formation and $\mathrm{N}_{2}$ reduction were found to be catalyzed by the same enzyme complex, nitrogenase.

\section{2}

In his doctoral degree thesis, L.N.M. Duysens describes a powerful approach to understanding the effects caused by illumination of photosynthetic cells, difference spectroscopy (see a photograph of the cover page of this classical thesis in Govindjee et al. 2003; see pp. 6 and 7). His experiments with Rsp. rubrum revealed that one prominent effect corresponded to 'photo-oxidation' of a cytochrome (Duysens 1952). In his thesis Duysens discovered absorption changes in a fraction of $\mathrm{BChl}$, and named it ' $\mathrm{P}$ ' for pigment, for example, $\mathrm{P} 870$.

\section{3}

L.P. Vernon discovers the presence of large quantities of cytochrome $c$ in Rsp. rubrum cells grown photosynthetically under anaerobic conditions.

Helge Larsen's $\mathrm{PhD}$ thesis on photosynthetic green sulfur bacteria describes conditions for optimal growth of C. limicola and C. thiosulfatophilum, and compares their distinguishing characteristics. Quantum yield measurements with various inorganic electron donors indicated a minimum quantum number of about 8 .

\section{4}

J. Postgate observes cytochrome in the strict anaerobe Desulfovibrio desulfuricans. This finding led to research of great import for understanding the energy metabolism of anaerobic organisms that use inorganic terminal oxidants such as sulfate.

Albert Frenkel discovers that membrane fragments obtained by disruption of Rsp. rubrum cells (see 1959) can rapidly phosphorylate ADP when illuminated anaerobically in the absence of electron donors or acceptors (Frenkel 1954).

1957

G. Cohen-Bazire, W.R. Sistrom, and R.Y. Stanier systematically investigate the overall effects of light and $\mathrm{O}_{2}$ on synthesis of $\mathrm{BChl}$ and carotenoids in Rps. sphaeroides and Rsp. rubrum. This work provided basic guidelines for later biochemical and molecular biological analysis of regulatory mechanisms that control photopigment production in purple bacteria (Cohen-Bazire et al. 1957).

\section{9}

Prior to the 1959 report of Tuttle and Gest (1959), the photopigments of purple photosynthetic bacteria were believed to be localized in small intracellular 'organelles' called 'chromatophores,' as first demonstrated by Pardee et al. (1952). They found, however, that lysis of Rsp. rubrum cells did not release free chromatophores. Lysis yielded pigmented membranes capable of photophosphorylation of ADP. It became evident that 'in vivo the photosynthetic apparatus of the photosynthetic bacteria is associated with the cytoplasmic membrane and/or membranous extensions in the cytoplasm of the cell.'

A.A. Krasnovsky proposes that the pigments in green photosynthetic bacteria are organized as oligomeric complexes (Krasnovsky and Pakshina 1959). This organizational model is finally confirmed in the 1980s (Smith et al. 1983).

R. Clinton Fuller and Martin Gibbs show that purple bacteria contain the Calvin-Benson cycle of carbon fixation (Fuller and Gibbs 1959).

\section{0}

Clayton and Smith report on the Rps. sphaeroides blue-green mutant R-26, which became a preferred strain for research in many biophysical laboratories and the source of the reaction center preparations used for many spectroscopic and structural studies 
(Clayton and Smith 1960). For more details, see Clayton (2002).

\section{2}

L.E. Mortenson and colleagues isolate and describe a low redox potential Fe protein obtained from extracts of the anaerobe Clostridium pasteurianum, and name it ferredoxin. The protein is required as an electron carrier in $\mathrm{N}_{2}$ fixation and in the conversion of pyruvate to acetyl $\mathrm{CoA}+\mathrm{CO}_{2}+\mathrm{H}_{2}$. Various ferredoxins were soon recognized as important redox catalysts in photosynthetic and other kinds of metabolic processes. Historical aspects are discussed in Mortenson (1963) and Lovenberg (1974).

John Olson discovers the bacteriochlorophyll $a$ antenna protein, later renamed as the FMO (Fenna: Matthews: Olson) protein in green sulfur bacteria (Olson and Romano 1962). See also Olson, this issue.

\section{3}

W.R. Sistrom, B.M. Ohlsson and J. Crounce isolate the first mutant with a defective photosystem. The mutant PM-8 was found among the survivors of ultraviolet light-irradiated cells (Sistrom et al. 1963). It showed no gross changes in photopigment synthesis, was able to grow under semi-aerobic conditions, but could not grow anaerobically with light as the energy source. PM-8 exhibited none of the reversible light-induced absorbancy changes detectable in the wild-type parental strain. Later research showed that membranes of the mutant lacked three protein components associated with reaction center $\mathrm{BChl}$.

Wim Vredenberg and L.N.M. Duysens analyze fluorescence in Rps. rubrum and propose that energy transfer in photosynthetic bacteria can take place from one photosynthetic unit to the next, giving rise to the concept of 'puddle' and 'lake' organization of antenna systems (Vredenberg and Duysens 1963).

The first international symposium on bacterial photosynthesis was held in Yellow Springs, Ohio. Investigators from a number of countries met to exchange information at this informal meeting sponsored by the C.F. Kettering Foundation. The proceedings of the meeting were published in 'Bacterial Photosynthesis,' edited by H. Gest, L.P. Vernon and A. San Pietro, Antioch Press, Yellow Springs, Ohio, 1963. The 77 participants in the meeting included almost all of the leading investigators of bacterial photosynthesis, as well as a number of prominent researchers of oxygenic photosynthesis. Also see Vernon (2003).

R.K. Clayton proposes the name 'reaction center' to describe the complex that catalyzes lightdriven photosynthetic electron transfer. Early efforts to isolate this complex were carried out by Clayton by photodegradation or chemical oxidation of the antenna pigments, leaving behind the more robust reaction center (Clayton 1963). See also Clayton (2002).

C. Sybesma and J. Olson carry out the first quantitative studies of energy transfer efficiency in green sulfur bacteria (Sybesma and Olson 1963).

\section{4}

G. Cohen-Bazire and coworkers describe the unique structures observed in electron micrographs of green sulfur bacteria, and refer to them as 'chlorobium vesicles,' later designated as 'chlorosomes' (Cohen Bazire et al. 1964).

\section{6}

M.C.W. Evans, B.B. Buchanan and D.I. Arnon propose a new $\mathrm{CO}_{2}$ reduction cycle to account for photoautotrophy in Chlorobium (Evans et al. 1966). Accordingly, two ferredoxin-linked carboxylation reactions facilitate reversal of reactions of the tricarboxylic acid (TCA) cycle, permitting conversion of $\mathrm{CO}_{2}$ to acetyl-CoA. In 1966, evidence for operation of the 'reductive TCA cycle' was incomplete. Subsequent research, notably by Sirevåg (1995), provided the missing evidence. See also Ormerod (2003).

Don DeVault and Britton Chance report the temperature-independent photooxidation of cytochromes in Chromatium vinosum, the first evidence for quantum mechanical tunneling processes in any biological system (DeVault and Chance 1966).

Drews and Giesbrecht (1966) publish a description of Rhodopseudomonas viridis, which later was used as the source of material to obtain reaction center crystals to solve the 3D structure (see 1984).

\section{8}

D.W. Reed and R.K. Clayton report the isolation of a photosynthetic reaction center complex from Rps. sphaeroides (Reed and Clayton 1968). 
W. Parson uses kinetic spectroscopy on chromatophore membranes of $C$. vinosum to establish that $\mathrm{P} 870$ oxidation is the primary reaction in bacterial photosynthesis, and that a cytochrome is oxidized as $\mathrm{P} 870^{+}$ is rereduced (Parson 1968). See also Parson (2003).

\section{9}

J.B. Jackson and A. Crofts utilize potassium diffusion potentials to calibrate the carotenoid bandshift as a measure of membrane electrical potential (Jackson and Crofts 1969).

\section{0}

A. Borisov and V. Godik determine fluorescence lifetime of bacteriochlorophyll in purple bacterial membranes (Borisov and Godik 1970). See also Borisov (2003).

\section{1}

June Lascelles and David Wertlieb describe mutants of Rps. sphaeroides that produced large amounts of $\mathrm{BChl}$ and carotenoids under highly aerobic conditions in darkness (Lascelles and Wertleib 1971). They concluded that 'the insensitivity of the mutants to $\mathrm{O}_{2}$ repression is due to defects in the regulatory system which controls formation of the enzymes concerned in pigment synthesis.'

R.C. Fuller and coworkers report highly enriched, photochemically active membrane preparation from green sulfur bacteria (Fowler et al. 1971).

George Feher reports extensive characterization of the composition and properties of the Rps. sphaeroides $R-26$ reaction center complex (Feher 1971).

\section{2}

Les Dutton and coworkers discover the $\mathrm{T}_{0}$ spinpolarized triplet EPR signal from photosynthetic bacteria (Dutton et al. 1972). M. Thurnauer, J.J. Katz and J. Norris, later in 1975, explain the spin polarization in terms of the radical pair theory, which establishes that the electronic state that precedes electron transfer is an excited singlet state (Thurnauer et al. 1975).

Oelze and Drews suggest adoption of the term 'intracytoplasmic membrane' to describe the invaginated membrane system that houses the photosynthetic apparatus in purple bacteria (Oelze and Drews 1972). Intracytoplasmic membrane had been used earlier by Marr and co-workers to describe the structures in which the respiratory enzymes of Azotobacter agilis (Pangborn et al. 1962) and the BChl of Rsp. rubrum (Holt and Marr 1965) are localized. See also Drews and Niederman (2002).

\section{3}

Colin Wraight and R. Clayton determine the absolute quantum yield of photochemistry in isolated reaction centers from purple bacteria to be 1.0 (Wraight and Clayton 1973).

\section{4}

Barry Marrs discovers a genetic recombination system in Rps. capsulata (Marrs 1974). Gene transfer is mediated by a 'bacteriophage-like' entity called 'gene transfer agent' (GTA). GTA later proved to be very useful for mapping the location and order of photosynthesis genes. See also Marrs (2002).

B.K. Pierson and R.W. Castenholz report on a 'phototrophic, gliding, filamentous bacterium of hot springs, Chloroflexus aurantiacus.' This bacterium is the most thermophilic of known anoxyphototrophs. Some strains can grow at $70^{\circ} \mathrm{C}$ (Pierson and Castenholz 1974).

\section{5}

William Parson and coworkers observe the optical transients $\mathrm{P}_{\mathrm{F}}$ and $\mathrm{P}_{\mathrm{R}}$ states in reaction centers from purple bacteria using nanosecond optical spectroscopy. These states are later identified as the chargeseparated state $\mathrm{P}_{870}{ }^{+} \mathrm{BPh}^{-}$and the triplet state of P870, respectively (Parson et al. 1975). See also Parson (2003).

First picosecond spectroscopic studies on reaction centers from purple bacteria are carried out by Parson and coworkers and independently by Dutton, Rentzepis and colleagues. These studies establish that bacteriopheophytin is an early electron acceptor (Kaufmann et al. 1975; Rockley et al. 1975). See also Parson (2003).

R. Fenna and B. Matthews determine the X-ray structure of the bacteriochlorophyll $a$ protein, now 
known as the Fenna-Matthews-Olson or FMO protein, using protein provided by J. Olson. This was the first X-ray structure of a photosynthetic pigmentprotein (Fenna and Matthews 1975). See also Olson, this issue.

Extraction and reconstitution experiments by Melvin Okamura, George Feher and coworkers show that ubiquinone is the first stable electron acceptor in reaction centers from Rps. sphaeroides (Okamura et al. 1975).

E. Broda publishes 'The Evolution of the Bioenergetic Processes' (Broda 1975). His analysis considered bioenergetic mechanisms in all forms of life, and the literature coverage was extensive. Broda's 'conversion hypothesis' proposed that many aerobic non-photosynthetic prokaryotes descended from purple photosynthetic bacteria and that 'membrane bound photosynthetic electron flow chains were converted to respiratory chains.'

\section{6}

Barry Marrs and coworkers clones the photosynthesis gene cluster using illegitimate recombination between an R plasmid and the chromosome of Rps. capsulatus (Yen and Marrs 1976). See also Marrs (2003).

\section{7}

Colin Wraight and André Vermeglio independently discover the two electron gate in reaction centers from Rps. sphaeroides (Verméglio 1977; Wraight 1977). See also Verméglio (2002).

T. Monger and W. Parson deduce elements of the membrane organization of antenna complexes in Rps. sphaeroides from triplet quenching experiments (Monger and Parson 1977).

\section{8}

K. Sato and K. Harashima report the presence of BChl $a$ in certain marine aerobic heterotrophic bacteria that are unable to grow anaerobically with light as the energy source. From subsequent research it appears that such organisms can use light as a supplementary energy source under certain conditions; see Harashima et al. (1989). More recently, organisms of this kind have been designated as 'aerobic anoxygenic phototrophic bacteria' (Beatty 2002), and found to make up a significant portion of the marine microbial community in some ocean surface locations (Kolber et al. 2000).

Andrew Staehelin and coworkers carry out freeze fracture electron microscopic analysis of chlorosomes from $C$. aurantiacus and propose a detailed structural model (Staehelin et al. 1978).

V. Shuvalov and coworkers identify bacteriochlorophyll as the first electron acceptor in purple bacterial photosynthesis (Shuvalov et al. 1978).

\section{9}

T. Swarthoff and J. Amesz prepare a highly enriched reaction center particle from the green sulfur bacterium Prosthecochloris aestuarii (Swarthoff and Amesz 1979).

\section{1}

H. Zuber and coworkers determine the complete protein sequence of an LH1 (light-harvesting) antenna protein from Rsp. rubrum (Brunisholz et al. 1981).

\section{3}

JoAnn Williams and coworkers determine the gene sequence for reaction center proteins from $R b$. sphaeroides (Williams et al. 1983).

H. Gest and J. Favinger isolate Heliobacterium chlorum, the first representative of the Gram positive heliobacteria family (Gest and Favinger 1983). The heliobacteria contain a novel form of BChl (BChl $g$ ) that is closely related to chlorophyll $a$. Heliobacteria are also distinctive in that the reaction center is of the Photosystem I type and its protein moiety consists of a single homodimeric polypeptide (see 1992-1993).

Beverly Pierson and Philip Thornber prepare reaction centers from the green filamentous bacterium C. aurantiacus (Pierson and Thornber 1983).

\section{4}

John Hearst's research group publishes the nucleotide sequence of the reaction center and LH1 structural genes of Rhodobacter capsulatus (Youvan et al. 1984). This work gave clues about the membrane structure 
(i.e., transmembrane segments) and similarities to reaction center apoproteins of plants (Hearst and Sauer 1984).

Johann Deisenhofer and colleagues report electron density and chromophore structure of the reaction center complex from Rps. viridis (Deisenhofer et al. 1984). The structure of the complete protein complex is published shortly thereafter (Deisenhofer et al. 1985). This is the first structure at atomic $(3 \AA)$ resolution of a protein complex from a biological membrane. See also Allen (2004).

Michael Madigan isolates the 'mildly thermophilic' Thermochromatium tepidum, whose optimal growth temperature is $50^{\circ} \mathrm{C}$. This bacterium contains a novel LHI photopigment complex that absorbs maximally near $920 \mathrm{~nm}$ (Madigan 1984). See also Madigan (2003).

\section{5}

R.C. Fuller and coworkers identify reaction center from $H$. chlorum and establish that the primary donor is BChl $g$ absorbing at $800 \mathrm{~nm}$ (Fuller et al. 1985). Further work establishes that the reaction center is of Type I (Prince et al. 1985).

\section{7}

Douglas Youvan and E. Bylina construct the first sitedirected mutants of bacterial reaction centers (Bylina and Youvan 1987).

George Feher and colleagues crystallize the reaction center of $R b$. sphaeroides R-26 and determine its structure (Allen et al. 1987). See also Allen, this issue.

\section{8}

J. Deisenhofer, R. Huber and H. Michel awarded the Nobel Prize in Chemistry for determination of the structure of the photosynthetic reaction center, the first integral membrane protein to have its structure determined at high resolution.

\section{9}

J. Trost and R. Blankenship prepare reaction centers from Heliobacillus mobilis. The purified complex contains only a single type of polypeptide, which later work establishes to be a protein homodimer (Trost and Blankenship 1989).

Paddock et al. (1989) propose proton donors to $\mathrm{Q}_{\mathrm{B}}$ in reaction centers from $R b$. sphaeroides. Subsequent work leads to the outline of a proton pathway (范elroth et al. 2001).

\section{2-1993}

Gene sequence of reaction center proteins was obtained for $C$. limicola and H. mobilis, establishing that these reaction centers are a homodimer of two identical core proteins (Büttner et al. 1992; Liebl et al. 1993).

\section{3}

F. Widdel and coworkers discover photoautotrophic growth of purple bacteria on $\mathrm{CO}_{2}$ with $\mathrm{Fe}^{2+}$ as the electron donor (Widdel et al. 1993) This growth mode has significant implications for hypotheses of early life on Earth, and could explain the deposition of bandediron formations in an assumed anoxic biosphere in Archean times.

\section{4}

Carl Bauer and coworkers discover photoactic behavior of Rhodospirillum centenum. Colonies of the bacterium on agar move toward a light source whose spectrum overlaps the in vivo IR absorbancy bands of BChl (positive phototaxis) (Ragatz et al. 1994). Visible light that includes the $590 \mathrm{~nm}$ band of $\mathrm{BChl}$ and absorbancy maxima of carotenoids (475-550 nm) causes negative phototaxis.

C. Bauer's research group publishes a detailed mutational analysis of BChl biosynthesis genes that later proved to be important in identifying chlorophyll biosynthesis genes of cyanobacteria and plants (Bollivar et al. 1994). See also Bauer (this issue).

\section{5}

Richard Cogdell and colleagues determine the Xray crystal structure of the LH2 antenna complex from Rhodopseudomonas acidophila (McDermott et al. 1995). See also R. Cogdell et al. (this issue). 
Aartsma and coworkers report spectroscopic studies on single molecules of the LH2 antenna complex from purple bacteria (van Oijen et al. 1999).

\section{0}

Phylogenetic analysis of photosynthesis genes by Bauer's research group suggests that purple bacteria contain the most ancient Mg-tetrapyrrole biosynthesis genes (Xiong et al. 2000). Later work by Raymond and coworkers establishes that horizontal gene transfer has played a major role in the evolutionary development of photosynthesis (Raymond et al. 2002).

Kobayashi and coworkers identify the primary electron acceptor of green sulfur bacteria as a chlorophyll a derivative (Kobayashi et al. 2000).

A.S. Lang and J.T. Beatty report that the structural gene sequence and organization of the $R b$. capsulatus 'gene transfer agent' (GTA) are similar to that of double-stranded DNA phages, but that expression of these genes is regulated by a cellular two-component signal transduction system (Lang and Beatty 2000). GTA structural gene-like clusters were found in other $\alpha$-proteobacteria, suggesting a long evolutionary history of GTA-like elements and this group of bacteria (Lang et al. 2002).

\section{Acknowledgment}

This paper was edited by J. Thomas Beatty and Govindjee.

\section{Appendix A}

The names of anoxygenic photosynthetic bacteria are given in the time line as they appeared in original publications. During the recent past, some over-zealous taxonomists have proposed changing the names of many organisms that were, and still are, important in experimental research. This unfortunate development is discussed in several papers by one of the authors (HG), most recently in Gest (2001) and by Nimis (2001). As an aid to those who may be perplexed by the apparent multiplication of different names for the same organism in the recent literature, original and alternative names of a number of anoxyphototrophs are given below.

For those interested in further historical details, a list of reference sources is appended to the time line as Appendix B.

\begin{tabular}{|c|c|}
\hline 'Traditional' name & Alternative names \\
\hline Chlorobium thiosulfatophilum & Chlorobium limicola \\
\hline Chromatium vinosum & Allochromatium vinosum \\
\hline Chromatium gracile & Marichromatium gracile \\
\hline Rhodopseudomonas viridis & Blastochloris viridis \\
\hline Rhodopseudomonas capsulata & Rhodobacter capsulatus \\
\hline Rhodopseudomonas sulfidophila & $\begin{array}{l}\text { Rhodobacter sulfidophilus } \\
\text { Rhodovulvum sulfidophilum }\end{array}$ \\
\hline Rhodopseudomonas sphaeroides & Rhodobacter sphaeroides \\
\hline Rhodopseudomonas gelatinosa & $\begin{array}{l}\text { Rhodocyclus gelatinosus } \\
\text { Rubrivivax gelatinosus }\end{array}$ \\
\hline Rhodospirillum centenum & Rhodocista centenaria \\
\hline Rhodospirillum molischianum & Phaeospirillum molischianum \\
\hline
\end{tabular}

\section{Appendix B. General references}

Blankenship RE (2002) Molecular Mechanisms of Photosynthesis. Blackwell Science, Oxford

Blankenship RE, Madigan MT and Bauer CE (eds) (1995) Anoxygenic Photosynthetic Bacteria. Kluwer Academic Publishers, Dordrecht, The Netherlands

Broda E (1975) The Evolution of the Bioenergetic Processes. Pergamon Press, Oxford

Clayton RK and Sistrom WR (eds) (1978) The Photosynthetic Bacteria. Plenum Press, New York

Drews G (1996) Forty-five years of developmental biology of photosynthetic bacteria. Photosynth Res 48: 325-352

Florkin M (1975) A History of Biochemistry. Part III. History of the Identification of the Sources of Free Energy in Organisms. Elsevier, Amsterdam

Gest H (1951) Metabolic patterns in photosynthetic bacteria. Bacteriol Rev 15: 183-210

Gest H (1963) Metabolic aspects of bacterial photosynthesis. In: Gest H, San Pietro A and Vernon LP (eds) Bacterial Photosynthesis, pp 129-150. Antioch Press, Yellow Springs, Indiana

Gest H (1966) Comparative biochemistry of photosynthetic processes. Nature 209: 879-882

Gest H (1982) The comparative biochemistry of photosynthesis: milestones in a conceptual zigzag. In: Kaplan NO and Robinson A (eds) From Cyclotrons to Cytochromes / Essays in Molecular Biology and Chemistry, pp 305-331. Academic Press, New York

Gest H (1988) Sun-beams, cucumbers, and purple bacteria/historical milestones in early studies of photosynthesis revisited. Photosynth Res 19: 287-308

Gest H (1993) History of concepts of the comparative biochemistry of oxygenic and anoxygenic photosynthesis. Photosynth Res 35: $87-96$

Gest H (1994) A microbiologist's odyssey: bacterial viruses to photosynthetic bacteria. Photosynth Res 40: 129-146

Gest H and Kamen MD (1960) The photosynthetic bacteria. In: Ruhland W, Ashby E, Bonner J, Geiger-Huber M, James WO, 
Lang A, Müller D and Stålfelt MG (eds) Encyclopedia of Plant Physiology, Vol V/2, pp 568-612. Springer-Verlag, Berlin

Harashima K, Shiba T and Murata N (eds) (1989) Aerobic Photosynthetic Bacteria. Japan Scientific Societies Press, Tokyo

Lascelles J (ed) (1973) Microbial Photosynthesis. Dowden, Hutchinson and Ross, Stroudsburg, Pennsylvania

Lovenberg W (1974) Ferredoxin and rubredoxin. In: JB Neilands (ed) Microbial Iron Metabolism, pp 161-185. Academic Press, New York

Ormerod JG (ed) (1983) The Phototrophic Bacteria: Anaerobic Life in the Light. Blackwell, Oxford

Peschek GA, Loffelhardt W and Schmetterer G (eds) (1998) The Phototrophic Prokaryotes. Kluwer Academic/Plenum Press, Dordrecht, The Netherlands

Schlegel HG (1999) Geschichte der Mikrobiologie. Deutsche Akademie der Naturforscher Leopoldina, Halle, Germany

\section{References}

Ädelroth P, Paddock ML, Tehrani A, Beatty JT, Feher G and Okamura MY (2001) Identification of the proton pathway in bacterial reaction centers: decrease of proton transfer rate by mutation of surface histidines at $\mathrm{H} 126$ and H128 and chemical rescue by imidazole identifies the initial proton donors. Biochemistry 40: $14538-14546$

Allen JP (2004) My daily constitutional in Martinsried. Photosynth Res 80: 157-163 (this issue)

Allen JP, Feher G, Yeates TO, Komiya H and Rees DC (1987) Structure of the reaction center from Rhodobacter sphaeroides R-26: the cofactors. Proc Natl Acad Sci USA 84: 5730-5734

Bauer C (2004) Regulation of photosystem synthesis in Rhodobacter capsulatus. Photosynth Res 80: 353-360 (this issue)

Beatty JT (2002) On the natural selection and evolution of the aerobic phototrophic bacteria. Photosynth Res 73: 109-114

Benson AA (2002) Following the path of carbon in photosynthesis: a personal story. Photosynth Res 73: 29-49

Bollivar DW, Suzuki JY, Beatty JT, Dobrowolski JM and Bauer CE (1994) Directed mutational analysis of bacteriochlorophyll a biosynthesis in Rhodobacter capsulatus. J Mol Biol 237: $622-640$

Borisov A (2003) The beginnings of research on biophysics of photosynthesis and initial contributions made by Russian scientists to its development. Photosynth Res 76: 413-426

Borisov A and Godik VI (1970) Fluorescence lifetime of bacteriochlorophyll and reaction center photooxidation in a photosynthetic bacterium. Biochim Biophys Acta 223: 441-443

Broda E (1975) The Evolution of the Bioenergetic Processes. Pergamon Press, Oxford

Brunisholz RA, Cuendet PA, Theiler R and Zuber H (1981) The complete amino acid sequence of the single light harvesting protein from chromatophores of Rs. Rubrum G-9. FEBS Lett 1229: $150-154$

Büttner M, Xie D-L, Nelson H, Pinther W, Hauska G and Nelson N (1992) Photosynthetic reaction center genes in green sulfur bacteria and in Photosystem I are related. Proc Natl Acad Sci USA 89: 8135-8139

Bylina EJ and Youvan DC (1987) Genetic-engineering of herbicide resistance - saturation mutagenesis of Isoleucine-229 of the reaction center L-subunit. Z Naturforsch J Biosci 42: 769-774
Clayton RK (1963) Toward the isolation of a photochemical reaction center in Rhodopseudomonas sphaeroides. Biochim Biophys Acta 75 : $312-323$

Clayton RK (2002) Research on photosynthetic reaction centers from 1932 to 1987. Photosynth Res 73: 63-71

Clayton RK and Smith C (1960) Rhodopseudomonas spheroides: high catalase and blue-green double mutants Biochem Biophys Res Commun 3: 143-145

Cogdell RJ, Hashimoto H and Gardiner AT (2004) Purple bacterial light-harvesting complexes: from dreams to structures. Photosynth Res 80: 173-179 (this issue)

Cohen-Bazire G, Sistrom WR and Stanier RY (1957) Kinetic studies of pigment synthesis by non-sulfur purple bacteria. J Cell Comp Physiol 49: 25-68

Cohen-Bazire G, Pfennig N and Kunisawa R (1964) The fine structure of green bacteria. J Cell Biol 22: 207-225

Deisenhofer J, Epp O, Miki F, Huber R and Michel H (1984) X-ray structure analysis of a membrane protein complex: electron density map at $3 \AA$ resolution and a model of the chromophores of the photosynthetic bacterium Rhodopseudomonas viridis. J Mol Biol 180: $385-398$

Deisenhofer J, Epp, Miki F, Huber R and Michel H (1985) Structure of the protein subunits in the photosynthetic bacterium Rhodopseudomonas viridis at $3 \AA$ resolution. Nature 318: 618-624

DeVault D and Chance B (1966) Studies of photosynthesis using a pulsed laser. I. Temperature dependence of cytochrome oxidation rate in Chromatium. Evidence for tunneling. Biophys J 6: 825-847

Drews G and Giesbrecht P (1966) Rhodopseudomonas viridis, nov. spec. ein neu isoliertes, obligat phototrophes Bakterium. Arch Mikrobiol 53: 255-262

Drews G and Niederman RA (2002) Membrane biogenesis in anoxygenic photosynthetic prokaryotes. Photosynth Res 73: 87-94

Dutton PL, Leigh JS and Seibert M (1972) Primary processes in photosynthesis: In situ ESR studies on the light-induced oxidized and triplet state of reaction center bacteriochlorophyll. Biochem Biophys Res Commun 46: 406-413

Duysens LNM (1952) Transfer of excitation energy in photosynthesis. Doctoral thesis. State University Utrecht, The Netherlands

Emerson R and Arnold W (1932a) A separation of the reactions in photosynthesis by means of intermittent light. J Gen Physiol 15: $391-420$

Emerson R and Arnold W (1932b) The photochemical reaction in photosynthesis. J Gen Physiol 16: 191-205

Engelmann TW (1883) Bacterium photometricum: ein Beitrag zur vergleichenden Physiologie des Licht- und Farbensinnes. Archiv Physiol 30: 95-124

Evans MCW, Buchanan BB and Aronon DI (1966) A new ferredoxing dependent carbon reduction cycle in a photosynthetic bacterium. Proc Natl Acad Sci USA 35: 928-934

Feher G (1971) Some physical and chemical properties of a bacterial reaction-center particle and its primary photochemical reactants. Photochem Photobiol 14: 373-387

Fenna RE and Matthews BW (1975) Chlorophyll arrangement in a bacteriochlorophyll protein from Chlorobium limicola. Nature 258: 573-577

Fowler CF, Nugent NA and Fuller RC (1971) The isolation and characterization of a photochemically active complex from Chloropseudomonas ethylica. Proc Natl Acad Sci USA 68: 2278-2282 
Frenkel A (1954) Light-induced phosphorylation by cell-free preparations of photosynthetic bacteria. J Am Chem Soc 76: 5568-5569

Fuller RC and Gibbs M (1959) Intracellular and phylogenetic distribution of ribulose 1,5 diphosphate carboxylase and Dglyderaldehyde 3-phosphate dehydrogenases. Plant Physiol 34: 324-329

Fuller RC, Sprague SG, Gest H and Blankenship RE (1985) A unique reaction center from Heliobacterium chlorum FEBS Lett 182: 345-349

Gest H (2001) Taxonomic ambiguities: a case history. Int J Syst Evol Microbiol 51: 707-710

Gest H and Favinger JL (1983) Heliobacterium chlorum, an anoxygenic brownish-green photosynthetic bacterium containing a 'new' form of bacteriochlorophyll. Arch Microbiol 136: 11-16

Gest H and Kamen MD (1949) Photoproduction of molecular hydrogen by Rhodospirillum rubrum. Science 109: 558-559

Govindjee, Beatty JT and Gest H (2003) Celebrating the millennium-historical highlights of photosynthesis research, Part 2. Photosynth Res 76: 1-11

Hearst JE and Sauer K (1984) Protein sequence homologies between portions of the $\mathrm{L}$ and $\mathrm{M}$ subunits of reaction centers of Rhodopseudomonas capsulata and the $\mathrm{Q}_{\mathrm{B}}$-protein of chloroplast thylakoid membranes: a proposed relation to quinone-binding sites. Z Naturforsch 39C: 421-424

Holt SC and Marr AG (1965) Location of chlorophyll in Rhodospirillum rubrum. J Bacteriol 89: 1402-1412

Huzisige H and Ke B (1993) Dynamics of the history of photosynthesis research. Photosynth Res 38: 185-209

Jackson JB and Crofts AR (1969) High energy state of chromatophores of Rhodopseudomonas spheroides. FEBS Lett 4: 185-189

Kamen MD and Gest H (1949) Evidence for a nitrogenase system in the photosynthetic bacterium Rhodospirillum rubum. Science 109: 560

Kaufmann K, Dutton PL, Netzel TL, Leigh JS and Rentzepis PM (1975) Picosecond kinetics of events leading to reaction center bacteriochlorophyll oxidation. Science 188: 1301-1304

Kobayashi M, Oh-oka H, Akutsu S, Akiyama M, Tominaga K, Kise H, Nishida F, Watanabe T, Amesz J, Koizumi M, Ishida N and Kano H (2000) The primary electron acceptor of green sulfur bacteria, bacteriochlorophyll 663, is chlorophyll $a$ esterified with (delta)2,6-phytadienol. Photosyth Res 63: 269-280

Kolber ZS, van Dover CL, Niederman RA and Falkowski PG (2000) Bacterial photosynthesis in surface waters of the open ocean. Nature 407: 177-179

Krasnovsky AA and Pakshina EV (1959) The photochemical and spectral properties of bacterioviridin of green sulfur bacteria. Dokl Acad SSSR (English trans) 127: 215-218

Lang AS and Beatty JT (2000) Genetic analysis of a bacterial genetic exchange element: The gene transfer agent of Rhodobacter capsulatus. Proc Natl Acad Sci USA 97: 859-864

Lang AS, Taylor TA and Beatty JT (2002) Evolutionary implications of phylogenetic analyses of the gene transfer agent (GTA) of Rhodobacter capsulatus. J Mol Evol 55: 534-543

Lascelles J and Wertlieb D (1971) Mutant strains of Rhodopseudomonas spheroides which form photosynthetic pigments aerobically in dark - growth characteristics and enzymic activities. Biochim Biophys Acta 226: 328-340

Liebl U, Mockensturm-Wilson M, Trost JT, Brune DC, Blankenship RE and Vermaas W (1993) Single core polypeptide in the reaction center of the photosynthetic bacterium Heliobacillus mobilis - structural implications and relations to other Photosystems. Proc Natl Acad Sci USA 90: 7124-7128
Lovenberg W (1974) Ferredoxin and rubredoxin. In: Neilands JB (ed) Microbial Iron Metabolism, pp 161-185. Academic Press, New York

Madigan MT (1984) A novel photosynthetic purple bacterium isolated from a Yellowstone hot spring. Science 225: 313-315

Madigan MT (2003) Anoxygenic phototrophs from extreme environments. Photosynth Res 76: 157-171

Marrs B (1974) Genetic recombination in Rhodopseudomonas capsulata. Proc Natl Acad Sci USA 71: 971-973

Marrs BL (2002) The early history of the genetics of photosynthetic bacteria: a personal account. Photosynth Res 73: 55-58

McDermott G, Prince SM, Freer AA, Hawthornthwaite-Lawless AM, Papiz MZ, Cogdell RJ and Isaacs NW (1995) Crystal structure of an integral membrane light-harvesting complex from photosynthetic bacteria. Nature 374: 517-521

Molisch H (1907) Die Purpurbakterien nach neuen Untersuchungen. Gustav Fischer, Jena, Germany

Monger TG and Parson WW (1977) Singlet-triplet fusion in Rhodopseudomonas sphaeroides chromatophores. A probe of the organization of the photosynthetic apparatus. Biochim Biophys Acta 460: 393-407

Mortenson LE (1963) Nitrogen fixation: role of ferredoxin in anaerobic metabolism. Ann Rev Microbiol 17: 115-138

Nimis PL (2001) A tale from Bioutopia. Nature 413: 21

Oelze J and Drews G (1972) Membranes of photosynthetic bacteria. Biochim Biophys Acta 265: 209-239

Okamura MY, Isaacson RA and Feher G (1975) Primary acceptor in bacterial photosynthesis: obligatory role of ubiquinone in photoactive reaction centers of Rhodopsuedomonas sphaeroides. Proc Natl Acad Sci USA 72: 3491-3495

Olson JM (2004) The FMO protein. Photosynth Res 80: 181-187 (this issue)

Olson JM and Romano CA (1962) A new chlorophyll from green bacteria. Biochim Biophys Acta 59: 726-728

Ormerod JG (2003) Every dogma has its day: a personal look at carbon metabolism in photosynthetic bacteria. Photosynth Res 76: $135-143$

Ormerod JG, Ormerod KS and Gest H (1961) Light-dependent utilization of organic compounds and photoproduction of molecular hydrogen by photosynthetic bacteria; relationships with nitrogen metabolism. Arch Biochem Biophys 94: 449-463

Paddock ML, Rongey SH, Feher G and Okamura MY (1989) Pathway of proton transfer in bacterial reaction centers: Replacement of Glu 212 in the $\mathrm{L}$ subunit inhibits quinone $\left(\mathrm{Q}_{\mathrm{B}}\right)$ turnover. Proc Natl Acad Sci USA 86: 6602-6606

Pangborn J, Marr AG and Robrish SA (1962) Localization of respiratory enzymes in intracytoplasmic membranes of Azotobacter agilis. J Bacteriol 84: 669-678

Pardee AB, Schachman HK and Stanier RY (1952) Chromatophores of Rhodospirillum rubrum. Nature 169: 282-283

Parson WW (1968) The role of P870 in bacterial photosynthesis. Biochim Biophys Acta 153: 248-259

Parson WW (2003) Electron donors and acceptors in the initial steps of photosynthesis in purple bacteria: A personal account. Photosynth Res 76: 81-92

Parson WW, Clayton RK, Cogdell RJ (1975) Excited states of photosynthetic reaction centers at low redox potentials. Biochim Biophys Acta 387: 265-278

Pierson BK and Castenholz RW (1974) Phototrophic gliding filamentous bacterium of hot springs, Chloroflexus aurantiacus. Arch Microbiol 100: 5-24

Pierson BK and Thornber JP (1983) Isolation and spectral characterization of photochemical reaction centers from the thermophilic 
bacterium Chloroflexus aurantiacus strain J-10-fl. Proc Natl Acad Sci USA 80: 80-84

Prince RC, Gest H and Blankenship RE (1985) Thermodynamic properties of the photochemical reaction center of Heliobacterium chlorum. Biochim Biophys Acta 810: 377-384

Ragatz L, Jiang Z-Y, Bauer C and Gest H (1994) Phototactic purple bacteria. Nature 370: 104

Raymond J, Zhaxybayeva O, Gogarten JP, Gerdes SY and Blankenship RE (2002) Whole-genome analysis of photosynthetic prokaryotes. Science 298: 1616-1620

Reed D and Clayton RK (1968) Isolation of a reaction center fraction from Rhodopseudomonas sphaeroides. Biochem Biophys Research Commun 30: 471-475

Rockley MG, Windsor MW, Cogdell RJ, Parson WW (1975) Picosecond detection of an intermediate in the photochemical reaction of bacterial photosynthesis. Proc Natl Acad Sci USA 72: 2251-2255

Shibata K (1931) Carbon and Nitrogen Assimilation [in Japanese; English translation: Gest H and Togasaki RK (eds and translators 1975), Japan Science Press, Tokyo

Shuvalov VA, Klevanik AV, Sharkov AV, Matveetz YA and Kryukov PG (1978) Picosecond detection of BChl-800 as an intermediate electron carrier between selectively-excited P870 and bacteriopheophytin in Rhodospirillum rubrum reaction centers. FEBS Lett 91: 135-139

Sistrom WR Ohlsson BM and Crounce J (1963) Absence of lightinduced absorbancy changes in a mutant of Rhodopseudomonas sphaeroides unable to grow photosynthetically. Biochim Biophys Acta 75: 285-286

Sirevag R (1995) Carbon metabolism in green bacteria. In: Blankenship RE, Madigan MT and Bauer CE (eds) Anoxygenic Photosynthetic Bacteria pp 871-883. Kluwer Academic Publishers, Dordrecht, The Netherlands

Smith KM, Kehres LA and Fajer J (1983) Aggregation of the bacteriochlorophylls $c$, bacteriochlorophylls $d$, and bacteriochlorophylls $e$ : models for the antenna chlorophylls of green and brown photosynthetic bacteria. J Am Chem Soc 105: 1387-1389

Staehelin LA, Golecki JR, Fuller RC and Drews G (1978) Visualization of the supramolecular architecture of chlorosomes (Chlorobium type vesicles) in freeze-fractured cells of Chloroflexus aurantiacus. Arch Microbiol 119: 269-277

Swarthoff T and Amesz J (1979) Photochemically active pigmentprotein complexes from the green photosynthetic bacterium Prosthecochloris aestuarii. Biochim Biophys Acta 548: 427-432

Sybesma C and Olson JM (1963) Transfer of chlorophyll excitation energy in green photosynthetic bacteria. Proc Natl Acad Sci USA 49: 248-253

Thurnauer MC, Katz JJ and Norris JR (1975) The triplet state in bacterial photosynthesis: Possible mechanisms of the primary photo-act. Proc Natl Acad Sci USA 72: 3270-3274
Trost JT and Blankenship RE (1989) Isolation of a photoactive photosynthetic reaction center-core antenna complex from Heliobacillus mobilis. Biochemistry 28: 9898-9904

Tuttle AL and Gest H (1959) Subcellular particulate systems and the photochemical apparatus of Rhodospirillum rubrum. Proc Natl Acad Sci 45: 1261-1269

van Niel CB (1932) On the morphology and physiology of the purple and green sulphur bacteria. Arch Mikrobiol 3: 1-112

van Niel CB (1944) The culture, general physiology, morphology, and classification of the non-sulfur purple and brown bacteria. Bacteriol Rev 8: 1-118

van Oijen AM, Ketelaars M, Kohler J, Aartsma TJ and Schmidt J (1999) Unraveling the electronic structure of individual photosynthetic pigment-protein complexes. Science 285: 400-402

Verméglio A (1977) Secondary electron transfer in reaction centers of Rhodopseudomonas sphaeroides. Out-of-phase periodicity of two for the formation of ubisemiquinone and fully reduced ubiquinone. Biochim Biophys Acta 459: 516-524

Verméglio A (2002) The two-electron gate in photosynthetic bacteria. Photosynth Res 73: 83-86

Vernon LP (2003) Photosynthesis and the Charles F. Kettering Research Laboratory. Photosynth Res 76: 379-388

Vredenberg WJ and Duysens LMN (1963) Transfer of energy from bacteriochlorophyll to a reaction centre during bacterial photosynthesis. Nature 197: 355-357

Widdel F, Schnell S, Heising S, Ehrenreich A, Assmus B and Schink B (1993) Ferrous iron oxidation by anoxygenic phototrophic bacteria. Nature 362: 834-836

Williams JC, Steiner LA, Ogden RC, Simon ML and Feher G (1983) Primary structure of the $\mathrm{M}$ subunit of the reaction center from Rhodopseudomonas sphaeroides. Proc Natl Acad Sci USA 80: 6505-6509

Winogradsky S (1888) Zur Morphologie und Physiologie der Schwefelbakterien. Arthur Felix, Leipzig, Germany

Wraight CA (1977) Electron acceptors of photosynthetic bacterial reaction centers. Direct observation of oscillatory behaviour suggesting two closely equivalent ubiquinones. Biochim Biophys Acta 459: 525-531

Wraight CA and Clayton RK (1973) Absolute quantum efficiency of bacteriochlorophyll photooxidation in reaction centers of Rhodopseudomonas sphaeroides. Biochim Biophys Acta 333: 246-260

Xiong J, Inuoue K and Bauer CE (2000) Molecular evidence for the early evolution of photosynthesis. Science 289: 1724-1730

Yen H-C and Marrs BL (1976) Map of genes for carotenoid and bacteriochlorophyll biosynthesis in Rhodopseudomonas capsulata. J Bacteriol 126: 619-624

Youvan DC, Bylina EJ, Alberti M, Begusch H and Hearst JE (1984) Nucleotide and deduced polypeptide sequences of the photosynthetic reaction-center, B870 antenna and flanking polypeptides from $R$ b. capsulatus. Cell 37: 949-957 